\title{
Different Strategies to Anchor Organotin Methoxides on Silica and Their (Re)Use as Heterogeneous Catalysts for Transesterification Reactions
}

\author{
Roberta A. de Jesus, ${ }^{\oplus a}$ Poliana da Conceição, ${ }^{a}$ Jhosianna P. V. da Silva, ${ }^{a}$ \\ Nívea S. Brainer, ${ }^{a}$ Simoni M. P. Meneghetti ${ }^{\circledR a}$ and Mario R. Meneghetti ${ }^{\circledR}, a$ \\ ${ }^{a}$ Grupo de Catálise e Reatividade Química, Instituto de Química e Biotecnologia, \\ Universidade Federal de Alagoas, 57072-970 Maceió-AL, Brazil
}

\begin{abstract}
Catalysts were prepared by the heterogenization of the tributyltin(IV) methoxide $\left(n-\mathrm{Bu}_{3} \mathrm{Sn}(\mathrm{OMe})\right)$ and dibutyltin(IV) dimethoxide $\left(n-\mathrm{Bu}_{2} \mathrm{Sn}(\mathrm{OMe})_{2}\right)$ on silica by two strategies: $(i)$ anchoring of the organotin(IV) compounds on silica and (ii) anchoring of the organotin(IV) compounds on a silica gel functionalized with mercaptopropyl groups $\left(\mathrm{SiO}_{2}-\mathrm{SH}\right)$. The characterization results showed that, regardless of the method used to anchor the organotin species, the solids contained approximately $7-10 \%$ of Sn. The decrease or disappearance of the $\mathrm{O}-\mathrm{H}$ and $\mathrm{S}-\mathrm{H}$ stretching signals in the $\mathrm{SiO}_{2}$ and $\mathrm{SiO}_{2}-\mathrm{SH}$ spectra after the treatment with the organotin(IV) methoxide derivatives suggest the immobilization via $\mathrm{O}-\mathrm{Sn}$ or S-Sn covalent bonds. The catalytic performance was evaluated in methanolysis of ethyl acetate, in comparison to the analogous homogeneous systems, and the order of reactivity is $n-\mathrm{Bu}_{2} \mathrm{Sn}(\mathrm{OMe})_{2}>n-\mathrm{Bu}_{3} \mathrm{Sn}(\mathrm{OMe})>\mathrm{SiO}_{2}-\mathrm{SnBu}_{2}>\mathrm{SiO}_{2}-\mathrm{S}-\mathrm{SnBu}_{2}>\mathrm{SiO}_{2}-\mathrm{SnBu}_{3}>$ $\mathrm{SiO}_{2}-\mathrm{S}-\mathrm{SnBu}_{3}$. The solids on which the organotin species were directly immobilized on activated $\mathrm{SiO}_{2}$ showed catalytic efficiencies slightly higher than those immobilized on thiol-functionalized silica. All of the solid catalysts were recovered and reused for recycling studies and characterized again after the reuse tests. A better interaction between $n-\mathrm{Bu}_{3} \mathrm{Sn}(\mathrm{OMe})$ and both supports was observed, as verified by the low leaching of Sn after the first catalytic reaction.
\end{abstract}

Keywords: silica surface modification, anchoring, organotin catalysts, heterogeneous, transesterification

\section{Introduction}

Organotin(IV) compounds are the most widely used organometallic species in the world with such applications as fungicide, ${ }^{1}$ bactericide, ${ }^{2}$ polyvinyl chloride stabilizer, ${ }^{3}$ and antifouling paints for ships, ${ }^{4}$ and they are also widely used as industrial catalysts for several chemical transformations, such as (trans)esterification, ${ }^{5}$ hydrolysis of triacylglycerides, ${ }^{6}$ synthesis of polyurethanes, ${ }^{7}$ and other condensation processes that require Lewis acid catalysts. ${ }^{8}$

Possessing high catalytic activity and low cost, organotin(IV) compounds are usually applied under homogeneous reaction conditions without the recovery of the catalysts or their derivatives. However, several research groups have conducted studies to broaden the range of the organotin-based catalyst's applications to the generation of products that have a very low content of catalyst residues, the development of new systems that enable either the removal of the catalyst residue or, even better,

*e-mail: mrm@qui.ufal.br the recovery of the catalyst from the product and apply it in further reactions. ${ }^{9}{ }^{10}$ A promising alternative approach for overcoming this problem is based on the anchoring of organotin(IV) catalytic species on an insoluble support.

Indeed, organotin(IV) compounds have already been anchored on organic and inorganic supports, and the catalytic properties of these systems were evaluated using catalytic transesterification as a model reaction. ${ }^{11-18} \mathrm{In}$ particular, the polystyrene- $\left(\mathrm{CH}_{2}\right)_{11}-\mathrm{SnCl}_{3}$ catalytic system exhibited $76 \%$ conversion after $2 \mathrm{~h}$ for the transesterification between ethyl acetate and $n$-octanol, and additionally, low tin leaching was observed even after nine reaction cycles. ${ }^{18}$ Despite this interesting result, the use of inorganic supports is an excellent option because, similar to silica, they can be resistant to organic solvents, leading to improved thermal and chemical stability. ${ }^{19}$

The anchoring of a homogeneous catalyst on the silica via covalent bonds can be attained by a direct chemical reaction of the support with the catalyst or, more frequently, by prior functionalization of the silica surface with alkoxysilane groups containing alkyl substituents, 
most commonly bearing mercapto, vinyl, carboxyl, amine, imidazole or halogen functional groups. ${ }^{20-24}$

In this study, two types of tin-based catalysts supported on silica were prepared: $(i)$ direct anchoring of two organotin(IV) complexes on a nonfunctionalized silica gel $\left(\mathrm{SiO}_{2}-\mathrm{Sn}\right)$ and (ii) anchoring of the two tin(IV) complexes on a mercaptopropyl-functionalized silica gel $\left(\mathrm{SiO}_{2}-\mathrm{S}-\mathrm{Sn}\right)$. Indeed, these two approaches for anchoring organotin(IV) complexes are can be considered relatively simple in comparison to those usually reported in the literature, ${ }^{10-12}$ in which more elaborated and sensitive reagents are employed. Furthermore, at the end of the anchoring process, just simple washing of the solid is enough to remove the excess of the reagents, avoiding distillation or extraction steps.

The catalytic efficiency, recovery, and reuse of the catalysts were also investigated using the transesterification between ethyl acetate and methanol and, in some cases, benzyl benzoate and ethanol.

\section{Experimental}

\section{Reagents}

Tributyltin methoxide $\left(n-\mathrm{Bu}_{3} \mathrm{Sn}(\mathrm{OMe}), 97 \%\right.$, Aldrich, St. Louis, USA), dibutyltin dimethoxide $\left(n-\mathrm{Bu}_{2} \mathrm{Sn}(\mathrm{OMe})_{2}\right.$, 95\%, Gelest, Morrisville, USA), ethyl acetate (> 99.5\%, Dinâmica, Indaiatuba, Brazil), $n$-hexane (95\%, Aldrich, St. Louis, USA), $n$-methanol (> 99.5\%, Dinâmica, Indaiatuba, Brazil), and (3-mercaptopropyl)trimethoxysilane (95\%, Aldrich, St. Louis, USA) were used as received. Silica gel 60 (40-63 $\mu \mathrm{m}$, Merck, Darmstadt, Germany) was treated according to the procedure describing the anchoring methodology. All manipulations of air- and/or moisturesensitive compounds were performed using standard Schlenk lines under argon atmosphere or vacuum. Toluene (99.7\%, Dinâmica, Indaiatuba, Brazil) was dried and distilled from sodium/benzophenone (Aldrich, St. Louis, USA) prior to use.

\section{Catalysts characterizations}

The Fourier transform infrared spectra (FTIR) of the solids were obtained from $\mathrm{KBr}$ pellets using a Thermo Scientific-Nicolet IR200 FTIR (Waltham, USA) in the region from 4000 to $400 \mathrm{~cm}^{-1}$ with a resolution of $4 \mathrm{~cm}^{-1}$ and 64 scans. Nitrogen adsorption-desorption isotherms were measured at $-196.15^{\circ} \mathrm{C}(77 \mathrm{~K})$ with a Quantachrome Instrument NOVA 1200 volumetric adsorption analyzer (Boynton Beach, USA) to obtain the specific surface areas, pores diameters and volumes. The samples were degassed at $100{ }^{\circ} \mathrm{C}$ for $4 \mathrm{~h}$ prior to the measurements. ${ }^{25}$ Thermogravimetric analysis (TGA) was performed using a Shimadzu DTG-60H instrument (Kyoto, Japan) under a dynamic nitrogen atmosphere of $20 \mathrm{~mL} \mathrm{m^{-1 }}$ in the temperature range between 30 and $900{ }^{\circ} \mathrm{C}$ with a heating rate of $10{ }^{\circ} \mathrm{C} \mathrm{min}^{-1}$. Raman spectroscopy was performed with a Horiba Scientific-Jobin Yvon Xplora instrument (Kyoto, Japan) using a 532-nm laser and a 50× objective. The spectra were obtained with 10 acquisitions in $60 \mathrm{~s}$ with a spectrometer grid in 600 centered at $2000 \mathrm{~cm}^{-1}$. The determinations of the tin and sulfur contents were performed in an Spectro-Arcos inductively coupled plasma optical emission spectrometer (ICP OES) (Kleve, Germany). The samples were digested using a $30 \%$ $\mathrm{HNO}_{3}: \mathrm{HF}: \mathrm{H}_{2} \mathrm{O}_{2}$ mixture in $1: 2: 0.5$ ratio during $1 \mathrm{~h}$ at $100{ }^{\circ} \mathrm{C}$, in closed bottles in a digester block. Scanning electron microscopy (SEM) analyses were performed using a Philips FEG-XL30 instrument (Eindhoven, Netherlands) with a dispersive energy spectroscopy (EDS) analysis accessory operating at $3 \mathrm{kV}$ using secondary electrons (SE) reaching a resolution of $3 \mathrm{~nm}$.

Anchoring of $n-\mathrm{Bu}_{3} \mathrm{Sn}(\mathrm{OMe})$ and $n-\mathrm{Bu}_{2} \mathrm{Sn}(\mathrm{OMe})_{2}$ in silica gel

Silica gel was activated under vacuum at $450^{\circ} \mathrm{C}$ for $4 \mathrm{~h}$, cooled under vacuum and stored under argon atmosphere. Activated silica gel (2.0 g) was suspended in a solution of $n$-Bu $\mathrm{Bu}_{3} \mathrm{Sn}(\mathrm{OMe})(1.8 \mathrm{~mL}, 6.0 \mathrm{mmol})$ in toluene $(20 \mathrm{~mL})$. The mixture was maintained under stirring, reflux, and argon atmosphere for $24 \mathrm{~h}$. After cooling, the obtained white solid, $\mathrm{SiO}_{2}-\mathrm{SnBu}_{3}$, was recovered by filtration, washed with toluene $(4 \times 15 \mathrm{~mL})$ and vacuum dried at room temperature for $24 \mathrm{~h} .{ }^{26}$ The same procedure was adopted for the anchoring process of $n-\mathrm{Bu}_{2} \mathrm{Sn}(\mathrm{OMe})_{2}$, affording the $\mathrm{SiO}_{2}-\mathrm{SnBu}_{2}$ white solid.

Functionalization of the silica gel with (3-mercaptopropyl) trimethoxysilane

Activated silica gel (2.0 g) was suspended in a solution of (3-mercaptopropyl)trimethoxysilane $(2.0 \mathrm{~mL}, 10 \mathrm{mmol})$ in toluene $(20 \mathrm{~mL})$. The mixture was maintained under stirring, reflux, and argon for $24 \mathrm{~h}$. After cooling, the solid $\left(\mathrm{SiO}_{2}-\mathrm{SH}\right)$ was recovered by filtration, washed with methanol $(4 \times 16 \mathrm{~mL})$, and vacuum dried at $85^{\circ} \mathrm{C}$ for $24 \mathrm{~h} .{ }^{27}$

Anchoring of $n-\mathrm{Bu}_{3} \mathrm{Sn}(\mathrm{OMe})$ and $n-\mathrm{Bu}_{2} \mathrm{Sn}(\mathrm{OMe})_{2}$ in $\mathrm{SiO}_{2}-\mathrm{SH}$

A thiol-functionalized silica gel, $\mathrm{SiO}_{2}-\mathrm{SH}(2.0 \mathrm{~g})$, was suspended in a solution of $n-\mathrm{Bu}_{3} \mathrm{Sn}(\mathrm{OMe})(2.9 \mathrm{~mL}$, $10 \mathrm{mmol})$ in toluene $(20 \mathrm{~mL})$. The mixture was maintained under stirring, reflux, and argon for $24 \mathrm{~h}$. After cooling, the solid $\left(\mathrm{SiO}_{2}-\mathrm{S}-\mathrm{SnBu}_{3}\right)$ was recovered by filtration, washed 
with water, methanol, ethyl acetate, and hexane $(2 \times 20 \mathrm{~mL}$ each), and finally dried under vacuum at $60{ }^{\circ} \mathrm{C}$ for $15 \mathrm{~h} .{ }^{28}$ The same procedure was adopted for the anchoring process of $n-\mathrm{Bu}_{2} \mathrm{Sn}(\mathrm{OMe})_{2}$, affording the $\mathrm{SiO}_{2}-\mathrm{S}-\mathrm{SnBu}_{2}$ white solid.

\section{Catalytic tests, reuse and leaching essays}

The catalytic performance was evaluated based on the transesterification reaction of ethyl acetate $(1.2 \mathrm{~mL})$ in the presence of methanol $(2.5 \mathrm{~mL})$. All reactions were performed several times at room atmosphere in a 4-mL batch glass vial reactor coupled to a magnetic stirrer with an oil bath set to 80 or $120{ }^{\circ} \mathrm{C}$. For the tests, an ethyl acetate:methanol:Sn molar ratio of 1:5:0.005 was adopted, and for the heterogeneous tin(IV) complexes, the Sn content (see Table 1) was taken into account, and the molar ratio used in the experiment corresponded to $0.24 \%$ (wt.\%) of Sn in the reaction medium. Additionally, several experiments were performed using benzyl benzoate $(1.6 \mathrm{~mL})$ and ethanol $(2.5 \mathrm{~mL})$, at $120^{\circ} \mathrm{C}$ with the benzyl benzoate:ethanol:Sn molar ratio of 1:5:0.005.

Table 1. Tin and sulfur content determined by ICP OES

\begin{tabular}{lccc}
\hline Catalyst & $\mathrm{Sn} /$ wt.\% & $\mathrm{S} /$ wt.\% & $\mathrm{Sn} / \mathrm{S}$ molar ratio \\
\hline $\mathrm{SiO}_{2}-\mathrm{SnBu}_{3}$ & 7.4 & - & - \\
$\mathrm{SiO}_{2}-\mathrm{SnBu}_{2}$ & 7.3 & - & - \\
$\mathrm{SiO}_{2}-\mathrm{S}_{-}-\mathrm{SnBu}_{3}$ & 7.6 & 2.0 & 1.0 \\
$\mathrm{SiO}_{2}-\mathrm{S}-\mathrm{SnBu}_{2}$ & 9.8 & 2.0 & 1.3 \\
\hline
\end{tabular}

The ethyl acetate conversion (\%) was determined by quantification of the components present in the reaction mixture after a set reaction time using gas chromatography carried out with a Varian CP 3800 GC gas chromatograph equipped with an Rtx-1 capillary column (length: $30.0 \mathrm{~m}$, internal diameter: $0.32 \mathrm{~mm}$, film thickness: $3.0 \mu \mathrm{m}), \mathrm{H}_{2}$ as carrier gas and a flame ionization detector (FID). For the evaluation of benzyl benzoate conversion, an Rtx-5MS capillary column (length: $30.0 \mathrm{~m}$, internal diameter: $0.25 \mathrm{~mm}$, film thickness: $0.1 \mu \mathrm{m}$ ) was employed.

The potential reuse of the supported catalysts was evaluated by conducting the reaction for $2 \mathrm{~h}$ at $120^{\circ} \mathrm{C}$ and at the ester:alcohol:Sn molar ratio of 1:5:0.005. After the first reaction cycle, the catalyst was separated from the reaction mixture by filtration, washed three times with methanol, dried at $80^{\circ} \mathrm{C}$ for $1 \mathrm{~h}$, and reused for more $2 \mathrm{~h}$. This procedure was repeated for each cycle.

For the leaching tests, at each catalyst cycle (described above), the supernatant (obtained by the filtration procedure) was placed to react for an additional $2 \mathrm{~h}$. This procedure was repeated for each cycle.

\section{Results and Discussion}

To anchor the organotin(IV) species, two strategies were adopted: (a) direct reaction of the organotin(IV) methoxides with the silanol groups present on activated silica; and (b) reaction of the organotin(IV) methoxides with propylthiol functionalized silica. A schematic illustration of these two strategies is depicted in Figure 1.

Preparations and characterization of the activated $\mathrm{SiO}_{2}$

Regardless of the anchoring strategy used, the silica gel acting as the support was first activated at $450{ }^{\circ} \mathrm{C}$ for $4 \mathrm{~h}$ under vacuum. This process is necessary to remove the excess water adsorbed on the silica surface and make the necessary amount of silanol groups available on the silica surface, which enables the modification / functionalization of the support. ${ }^{29}$ The activation of the silica was confirmed by comparing the silica FTIR spectra obtained before and after the thermal treatment (Figure S1, Supplementary Information (SI) section). A strong reduction in the intensity of the band centered on $3470 \mathrm{~cm}^{-1}$ that is due to the $\mathrm{O}-\mathrm{H}$ stretching bonds is observed in the FTIR spectrum. In addition, the intensities of the bands for the vibrations at approximately $961 \mathrm{~cm}^{-1}$ that are related to the stretching of the $\mathrm{Si}-\mathrm{O}$ bond in the $\mathrm{Si}-\mathrm{OH}$ silanol groups, and of the absorption bands corresponding to the deformation vibrations of the adsorbed water molecules at $1642 \mathrm{~cm}^{-1}$ also decrease. The presence of the $\mathrm{SiO}_{2}$ network is confirmed by the presence of strong absorption bands at approximately $1200-1000,807$, and $454 \mathrm{~cm}^{-1}$ that are attributed to the asymmetric, symmetric, and bending vibrations of the $\mathrm{Si}-\mathrm{O}-\mathrm{Si}$ bonds, respectively. ${ }^{30,31}$ Similarly, TGA of the silica before and after the activation procedure (Figure S2, SI section) showed that a significant mass loss occurs between room temperature and $100{ }^{\circ} \mathrm{C}$ due to the ablation of the water adsorbed on the silica. Additionally, the elimination of water is observed from 100 to $800{ }^{\circ} \mathrm{C}$ due to the condensation of the silanol groups present on the silica surface and the organic fragments present on the functionalized silica. ${ }^{29,32}$

Preparations and characterization of the $\mathrm{SiO}_{2}-\mathrm{Sn}$ catalytic systems

Organotin(IV) derivatives were supported on silica via the reaction of the silanol groups present on the silica matrix with the organotin(IV) methoxides, $n$ - $\mathrm{Bu}_{3} \mathrm{Sn}(\mathrm{OMe})$ and $n-\mathrm{Bu}_{2} \mathrm{Sn}(\mathrm{OMe})_{2}$, leading to the formation of their respective organotin(IV) silanoxides derivatives, $\mathrm{SiO}_{2}-\mathrm{SnBu}_{3}$ and $\mathrm{SiO}_{2}-\mathrm{SnBu}_{2}$, as illustrated in Figure 1a. ${ }^{26}$ The amount 

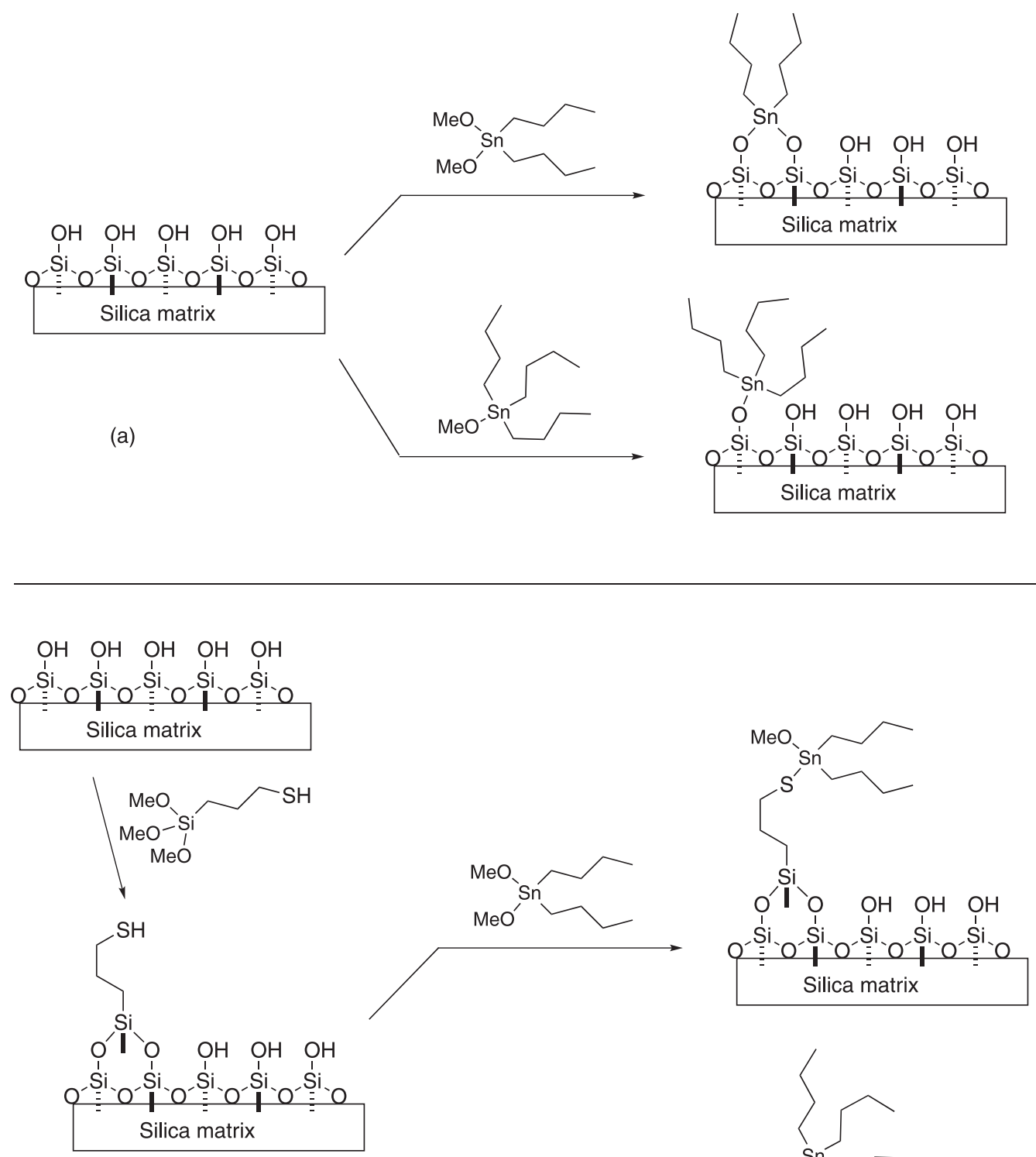

(b)
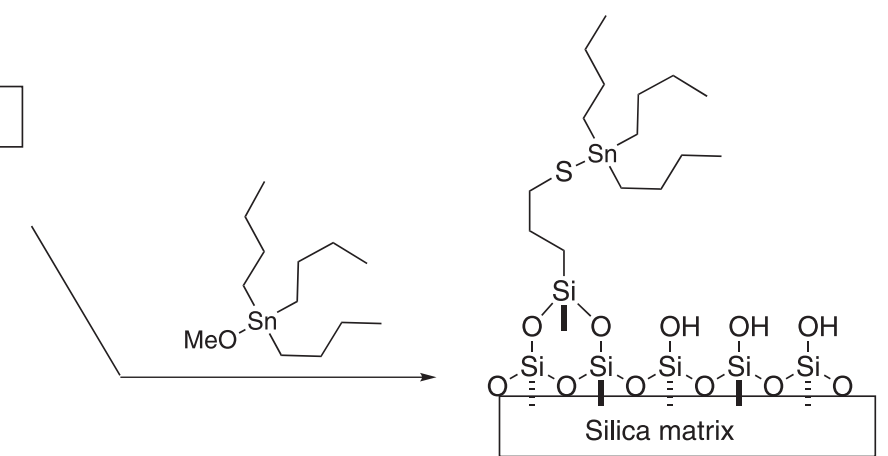

Figure 1. Strategies used to anchor organotin(IV)-based catalytic species: (a) direct reaction of the organotin(IV) methoxides with the silanol groups present on activated silica; and (b) reaction of the organotin(IV) methoxides with propylthiol functionalized silica.

of Sn effectively anchored on the $\mathrm{SiO}_{2}-\mathrm{Sn}$ systems was determined by ICP OES (see Table 1).

The FTIR spectra of the $\mathrm{SiO}_{2}-\mathrm{SnBu}_{3}$ and $\mathrm{SiO}_{2}-\mathrm{SnBu}_{2}$ solids confirmed the presence of the alkyltin moieties on the silica (see Figure 2). In addition to the typical bands related to the silica matrix, both systems display bands related to the stretching vibrations of the $\mathrm{C}-\mathrm{H}$ bonds of the $\mathrm{CH}_{3}$ and $\mathrm{CH}_{2}$ groups (from 2970 to $2790 \mathrm{~cm}^{-1}$ ), $\mathrm{CH}_{2}$ bend vibration $\left(1460 \mathrm{~cm}^{-1}\right)$, and some stretching vibrations of $\mathrm{Sn}-\mathrm{C}$ or
Sn-O bonds (between 500 and $700 \mathrm{~cm}^{-1}$ ), confirming the presence of the anchored organotin species. ${ }^{33}$

Preparation and characterization of the $\mathrm{SiO}_{2}-\mathrm{S}-\mathrm{Sn}$ catalytic systems

Another strategy used in this work to anchor the organotin(IV) derivatives on silica was based on the previous modification of the silica surface with the 


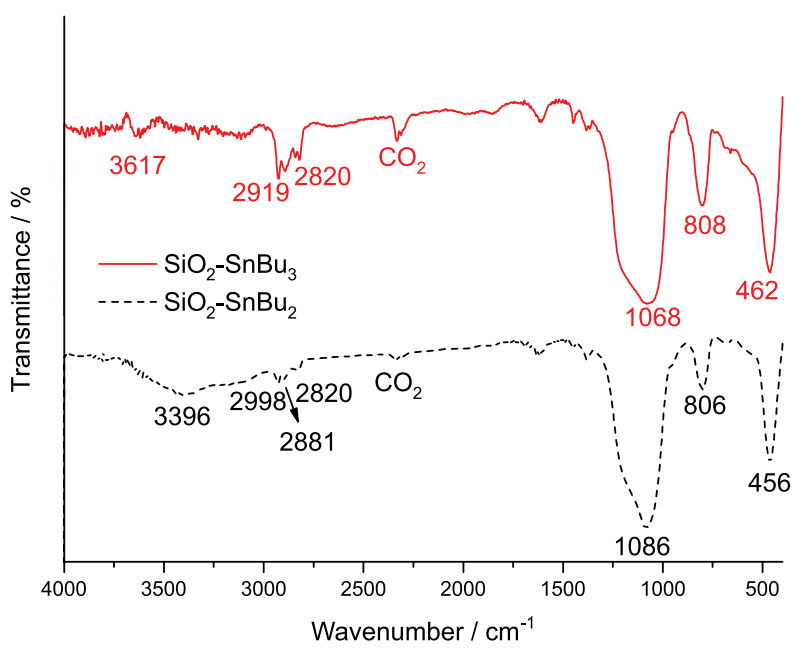

Figure 2. FTIR spectra of the $\mathrm{SiO}_{2}-\mathrm{SnBu}_{3}$ and $\mathrm{SiO}_{2}-\mathrm{SnBu}_{2}$ solids.

functional groups that interact with the organotin(IV) precursor. Thus, similar to hydroxyl groups, thiols are also able to react with organotin(IV) alkoxyde derivatives. ${ }^{28,34,35}$ Thiol-functionalized silica $\left(\mathrm{SiO}_{2}-\mathrm{SH}\right)$ was prepared by treating the activated silica with (3-mercaptopropyl) trimethoxysilane..$^{27} \mathrm{~A}$ schematic illustration of this reaction is depicted in Figure 1b. The modification of the silica surface was confirmed by FTIR analysis (see Figure 3a). In addition to the typical absorption bands associated with the vibrations of the silica network, the $\mathrm{SiO}_{2}-\mathrm{SH}$ FTIR spectrum showed vibrations at 2933, 2851, and $1430 \mathrm{~cm}^{-1}$ that are typically associated with the $\mathrm{C}-\mathrm{H}$ bonds in the structure of the modified solid. ${ }^{36}$ While vibrations associated with the presence of thiol groups were not detected, the presence of these functional groups on the solid was confirmed by Raman spectroscopy analysis. The Raman spectrum of $\mathrm{SiO}_{2}-\mathrm{SH}$ depicted in Figure $3 \mathrm{~b}$ shows the expected signals of the silica matrix, as well as the

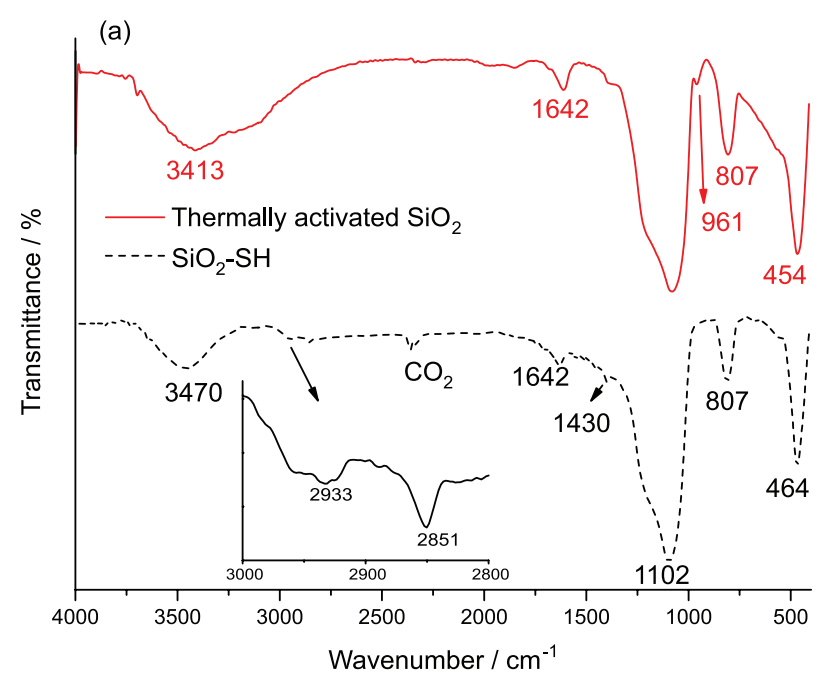

Figure 3. (a) FTIR and (b) Raman spectra of $\mathrm{SiO}_{2}-\mathrm{SH}$. signals related to the vibrations associated with the $\mathrm{CH}_{2}$ groups at 2892, 2938, and $1435 \mathrm{~cm}^{-1}$, and the vibrations related to the $\mathrm{SH}$ groups, $\mathrm{C}-\mathrm{C}$ bonds, and $\mathrm{C}-\mathrm{S}$ bonds at $2592 \mathrm{~cm}^{-1}, 1046 \mathrm{~cm}^{-1}$, and $658 \mathrm{~cm}^{-1}$, respectively. ${ }^{37}$ Also, Raman spectrum of $\mathrm{SiO}_{2}$ (Figure 3b) presents the typical absorption bands related to adsorbed water $\left(3390 \mathrm{~cm}^{-1}\right)$, $\mathrm{Si}-\mathrm{O}$ bond stretching of $\mathrm{Si}-\mathrm{OH}\left(989 \mathrm{~cm}^{-1}\right)$, symmetric vibrations of $\mathrm{Si}-\mathrm{O}-\mathrm{Si}\left(820 \mathrm{~cm}^{-1}\right)$ and siloxane ring breathing mode $\left.\left(488 \mathrm{~cm}^{-1}\right)\right)^{37,38}$

According to the reaction illustrated in Figure 1a, the $\mathrm{SiO}_{2}-\mathrm{S}-\mathrm{Sn}$ solids were prepared by mixing the thiolfunctionalized silica $\left(\mathrm{SiO}_{2}-\mathrm{SH}\right)$ with the $n-\mathrm{Bu}_{3} \mathrm{Sn}(\mathrm{OMe})$ and $n-\mathrm{Bu}_{2} \mathrm{Sn}(\mathrm{OMe})_{2}$ organotin(IV) methoxides in toluene under reflux, obtaining the $\mathrm{SiO}_{2}-\mathrm{S}_{-} \mathrm{SnBu}_{3}$ and $\mathrm{SiO}_{2}-\mathrm{S}-\mathrm{SnBu}_{2}$ catalytic systems, respectively. The amount of $\mathrm{Sn}$ actually anchored on the $\mathrm{SiO}_{2}-\mathrm{S}-\mathrm{Sn}$ systems was determined by ICP OES (Table 1).

The FTIR spectra of the $\mathrm{SiO}_{2}-\mathrm{S}-\mathrm{SnBu}_{3}$ and $\mathrm{SiO}_{2}-\mathrm{S}-\mathrm{SnBu}_{2}$ solids confirmed the presence of the organotin moieties on silica (see Figure 4a). In addition to the typical bands related to the silica matrix, both systems display the bands related to the stretching vibrations of the $\mathrm{C}-\mathrm{H}$ bonds of the $\mathrm{CH}_{3}$ and $\mathrm{CH}_{2}$ groups in the region from 2970 to $2850 \mathrm{~cm}^{-1}$, the $\mathrm{CH}_{2}$ bend vibrations at $1460 \mathrm{~cm}^{-1}$, and the Sn-C bond stretching vibrations at 660 and $680 \mathrm{~cm}^{-1} \cdot 33$

The Raman spectra of $\mathrm{SiO}_{2}-\mathrm{S}-\mathrm{SnBu}_{3}$ and $\mathrm{SiO}_{2}-\mathrm{S}-\mathrm{SnBu}_{2}$ are displayed in Figure $4 \mathrm{~b}$. In both materials, it was observed that the signal related to the $\mathrm{S}-\mathrm{H}$ bonds $\left(2592 \mathrm{~cm}^{-1}\right)$ detected for the previously modified silica $\left(\mathrm{SiO}_{2}-\mathrm{SH}\right.$, Figure $\left.3 \mathrm{~b}\right)$ disappeared. This result suggests that the reaction between the thiol groups and organotin(IV) methoxides occurred. Furthermore, the Raman spectra of both $\mathrm{SiO}_{2}-\mathrm{S}_{-} \mathrm{SnBu}_{3}$ and $\mathrm{SiO}_{2}-\mathrm{S}-\mathrm{SnBu}_{2}$ display the characteristic signals of

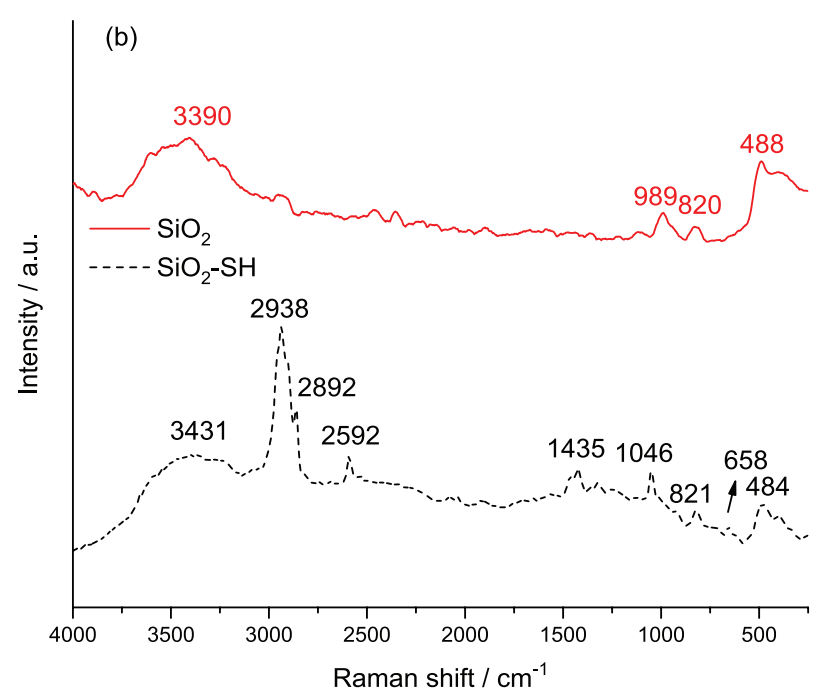



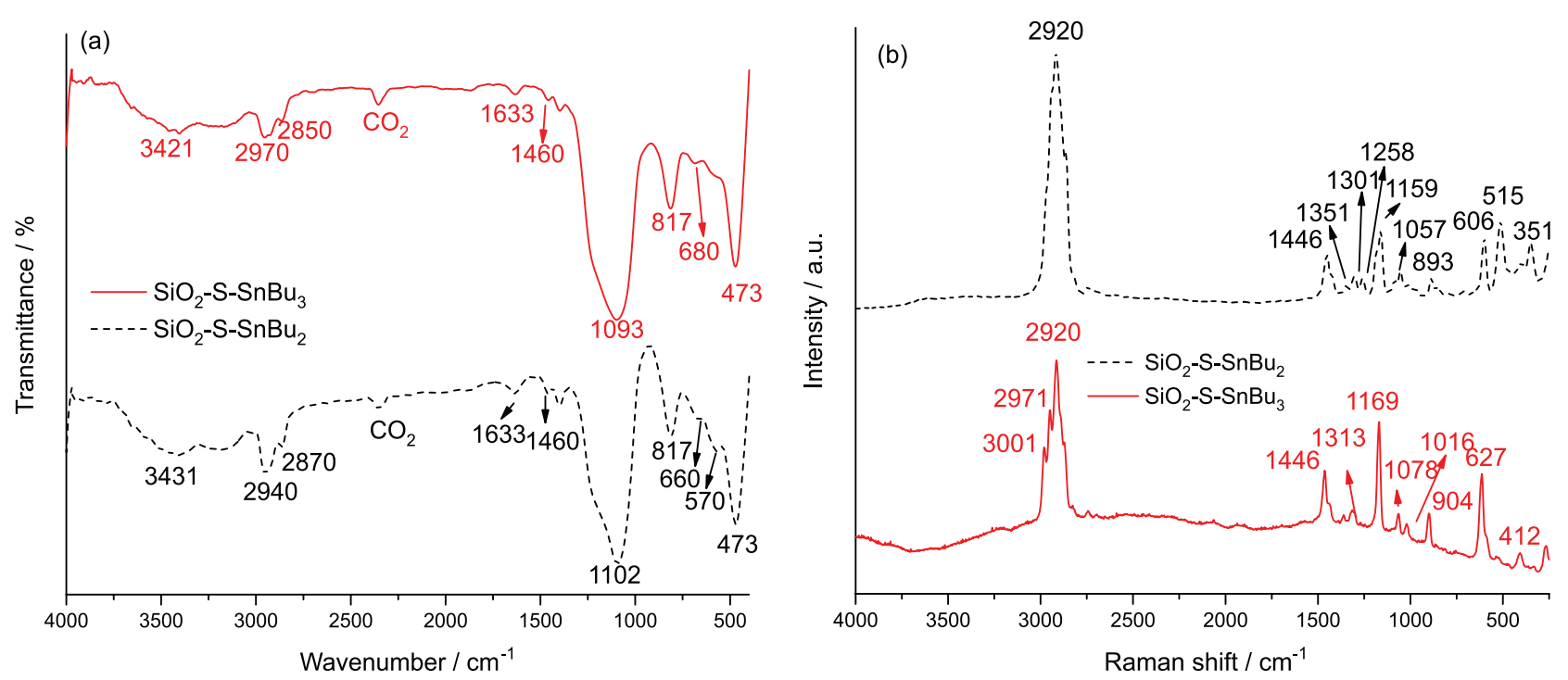

Figure 4. (a) FTIR and (b) Raman spectra of the $\mathrm{SiO}_{2}-\mathrm{S}-\mathrm{SnBu}_{3}$ and $\mathrm{SiO}_{2}-\mathrm{S}-\mathrm{SnBu}_{2}$ solids.

$\mathrm{C}-\mathrm{H}$ bond stretching vibrations of the alkyl moieties (from 3001 to $2900 \mathrm{~cm}^{-1}$ ), $\mathrm{CH}_{2}$ bend vibrations (between 1446 and $1258 \mathrm{~cm}^{-1}$ ), $\mathrm{C}-\mathrm{C}$ bond stretching vibrations (between 1169 and $\left.904 \mathrm{~cm}^{-1}\right)$, Sn-C bond stretching vibrations (627 and $606 \mathrm{~cm}^{-1}$ ), and $\mathrm{Sn}-\mathrm{S}$ bond stretching vibrations (412 and $351 \mathrm{~cm}^{-1}$ ). In particular, the Raman signal related to the $\mathrm{Sn}-\mathrm{O}$ vibration, due to the maintenance of some $\mathrm{Sn}-\mathrm{OMe}$ bonds, was observed at $515 \mathrm{~cm}^{-1}$ for $\mathrm{SiO}_{2}-\mathrm{S}-\mathrm{SnBu}_{2} \cdot{ }^{36-38}$

Considering the obtained FTIR and Raman spectra and the relative amounts of $\mathrm{Sn}$ and $\mathrm{S}$ ( $\mathrm{Sn} / \mathrm{S}$ molar ratio, Table 1), we suggest that for the $\mathrm{SiO}_{2}-\mathrm{S}-\mathrm{SnBu}_{3}$ system, the anchoring occurs mostly via the formation of the $\mathrm{S}-\mathrm{Sn}$ bonds because the $\mathrm{Sn} / \mathrm{S}$ molar ratio is ca. 1.0. For $\mathrm{SiO}_{2}-\mathrm{S}-\mathrm{SnBu}_{2}$, the $\mathrm{Sn} / \mathrm{S}$ molar ratio is higher than 1.0, suggesting that the organotin moiety may also be anchored by the interaction with the remaining silanol groups on the silica surface.

\section{Evaluation of the thermal stability of the solids}

The thermogravimetric profiles of the materials investigated in this work are shown in Figure S2 (SI section). It is confirmed that the not-activated $\mathrm{SiO}_{2}$ shows a mass loss of $6.5 \%$ between 30 and $150{ }^{\circ} \mathrm{C}$. At the same temperature range, a mass loss of $1.2 \%$ is observed for the thermally activated $\mathrm{SiO}_{2}$. In both systems, these mass losses are associated with the removal of the physisorbed water on the $\mathrm{SiO}_{2}$ surface. This difference between the two systems indicates that the thermal treatment was efficient because the mass loss is significantly lower for $\mathrm{SiO}_{2}$ after activation. ${ }^{29-32}$ The mass losses at the temperatures higher than $150{ }^{\circ} \mathrm{C}$ (between 150 and $800^{\circ} \mathrm{C}$ ) are approximately 5.5 and $2.8 \%$ for the not-activated $\mathrm{SiO}_{2}$ and activated
$\mathrm{SiO}_{2}$, respectively. In this temperature range, this behavior is mostly due to the ablation of water formed during the condensation of the silanol groups present on the silica surface. ${ }^{32,39}$ For all solids in which organic and / or organometallic species are present on the silica surface, important mass losses occurred between 150 and $800{ }^{\circ} \mathrm{C}$ (see Figure S2 and Table S1, SI section). These mass losses are related to the thermal decomposition of these organic and / or organometallic species supported on silica and also to the silanol condensation reactions. Among the solids containing the organotin species supported on silica, the systems in which the organotin species were directly supported on silica via the reaction with the silanol groups, namely $\mathrm{SiO}_{2}-\mathrm{SnBu}_{3}$ and $\mathrm{SiO}_{2}-\mathrm{SnBu}_{2}$, showed mass losses between 150 and $800{ }^{\circ} \mathrm{C}$ of 8.0 and $10 \%$, respectively. The systems in which the organotin species were supported on thiol-functionalized silica $\left(\mathrm{SiO}_{2}-\mathrm{SH}\right)$, namely $\mathrm{SiO}_{2}-\mathrm{S}-\mathrm{SnBu}_{3}$ and $\mathrm{SiO}_{2}-\mathrm{S}-\mathrm{SnBu}_{2}$, showed mass losses of $18 \% .^{39}$ The difference in the range of the mass loss between the $\mathrm{SiO}_{2}-\mathrm{Sn}$ and $\mathrm{SiO}_{2}-\mathrm{S}-\mathrm{Sn}$ systems is in accordance with the augmentation of the amount of supported species because the mass loss between 150 and $800{ }^{\circ} \mathrm{C}$ for $\mathrm{SiO}_{2}-\mathrm{SH}$ is approximately $10 \%$.

\section{Textural analysis of the solids}

Figure S3 (SI section) shows the nitrogen adsorption isotherms at $77 \mathrm{~K}$ of the solids investigated in this work. All solids show characteristic type IV isotherms, and the observation of hysteresis in these isotherms clearly suggest that all solids contain mesopores. ${ }^{40-42} \mathrm{It}$ is also observed that the modification of the silica surface leads to a decrease in the specific surface area, diameter and volume of pores, in 
all of the modified solids (Table 2). Additionally, the pore diameter distribution is shown in Figure S4 (SI section).

Table 2. Textural and structural properties of the solids investigated in this work

\begin{tabular}{lccc}
\hline Sample & $\mathrm{S}_{\text {BET }}{ }^{a} /\left(\mathrm{m}^{2} \mathrm{~g}^{-1}\right)$ & $\mathrm{V}^{\mathrm{b}} /\left(\mathrm{cm}^{3} \mathrm{~g}^{-1}\right)$ & $\mathrm{D}_{\text {ВJH }}{ }^{\mathrm{c}} / \mathrm{nm}$ \\
\hline Activated $\mathrm{SiO}_{2}$ & 478 & 0.9 & 6.0 \\
$\mathrm{SiO}_{2}-\mathrm{SnBu}_{3}$ & 271 & 0.5 & 4.5 \\
$\mathrm{SiO}_{2}-\mathrm{SnBu}_{2}$ & 173 & 0.3 & 4.5 \\
$\mathrm{SiO}_{2}-\mathrm{SH}$ & 362 & 0.5 & 5.0 \\
$\mathrm{SiO}_{2}-\mathrm{S}-\mathrm{SnBu}_{3}$ & 277 & 0.4 & 3.8 \\
$\mathrm{SiO}_{2}-\mathrm{S}-\mathrm{SnBu}_{2}$ & 160 & 0.2 & 3.9 \\
\hline
\end{tabular}

${ }^{\mathrm{a}} \mathrm{S}_{\mathrm{BET}}$ : Brunauer-Emmett-Teller (BET) surface area; ${ }^{\mathrm{b}} \mathrm{V}$ : pore volume; ${ }^{\mathrm{c}} \mathrm{D}_{\mathrm{BJH}}$ : Barrett-Joyner-Halenda (BJH) pore diameter. The specific surface areas, total pore volume, and pore diameters were calculated by the BET and BJH equations, respectively. ${ }^{25}$

The SEM images of the solids (Figure 5) show that all solids are formed by irregular grains with the sizes between 60 and $80 \mu \mathrm{m}$. It was verified that the procedures used to modify the silica surface did not compromise the main structure of the original silica grains. Furthermore, the elemental analysis of the solids also shows that the $\mathrm{Sn}$ and $\mathrm{S}$ elements are well distributed on the surface of the analyzed grains (see Figures S5-S7, SI section).

\section{Catalytic tests in methanolysis of ethyl acetate}

The catalytic efficiencies of the solids (activated $\mathrm{SiO}_{2}$, $\mathrm{SiO}_{2}-\mathrm{SH}, \mathrm{SiO}_{2}-\mathrm{SnBu}_{3}, \mathrm{SiO}_{2}-\mathrm{SnBu}_{2}, \mathrm{SiO}_{2}-\mathrm{S}-\mathrm{SnBu}_{3}$ and $\mathrm{SiO}_{2}-\mathrm{S}-\mathrm{SnBu}_{2}$ ) in methanolysis of ethyl acetate were investigated at 80 and $120{ }^{\circ} \mathrm{C}$ and for several reaction times in order to evaluate the heterogenization effect (by comparison with the corresponding homogeneous catalysts) and the viability of recycling (recovery and reuse of the catalysts).

The choice of this reaction is based on the fact that it is often used in order to simplify the studies, minimizing possible steric effects and mass transfer problems. ${ }^{12,43}$ In addition, the reaction can be conducted efficiently on a smaller scale using just a small amount of catalyst and the catalytic reaction can be easily followed by GC methodology.

According to the results presented in Figure 6, as expected, temperature has a positive effect on the activity of the catalytic systems. ${ }^{44}$ For the reaction in the absence of the organotin species, the conversion was not observed, even at the highest temperature tested $\left(120^{\circ} \mathrm{C}\right)$. Significant conversion was observed when the $n-\mathrm{Bu}_{3} \mathrm{Sn}(\mathrm{OMe})$ and $n$ - $\mathrm{Bu}_{2} \mathrm{Sn}(\mathrm{OMe})_{2}$ catalysts were used in homogeneous conditions. Of the two catalysts, $n-\mathrm{Bu}_{2} \mathrm{Sn}(\mathrm{OMe})_{2}$ was found to be more active in all of the studied conditions. The higher catalytic activity exhibited by $n-\mathrm{Bu}_{2} \mathrm{Sn}(\mathrm{OMe})_{2}$ can be related to $(i)$ the presence of two butyl ligands that causes less steric hindrance for the access of the substrate to the metal center compared to $n-\mathrm{Bu}_{3} \mathrm{Sn}(\mathrm{OMe})$ that contains three butyl ligands; and (ii) the higher Lewis acidity of this species that depends on the number of alkyl substituents on Sn, i.e., the Lewis acid character decreases with the increasing number of the alkyl substituents. ${ }^{43}$

Figure 7 displays the conversions of the catalytic systems bearing two alkyl groups on $\mathrm{Sn}$, namely $n$ - $\mathrm{Bu}_{2} \mathrm{Sn}(\mathrm{OMe})_{2}, \mathrm{SiO}_{2}-\mathrm{SnBu}_{2}$ and $\mathrm{SiO}_{2}-\mathrm{S}-\mathrm{SnBu}_{2}$. While all of the systems exhibited high activities at the reaction temperature of $120^{\circ} \mathrm{C}$, reaching the equilibrium conditions

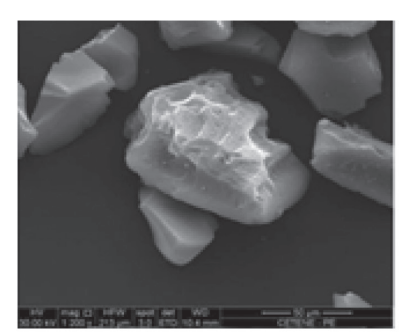

$\mathrm{SiO}_{2}$

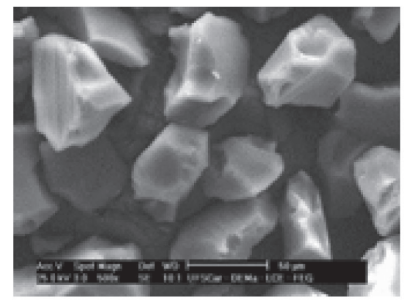

$\mathrm{SiO}_{2}-\mathrm{SH}$

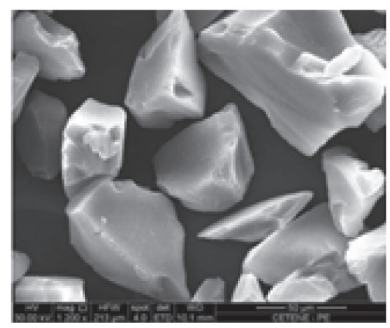

$\mathrm{SiO}_{2}-\mathrm{SnBu}_{3}$

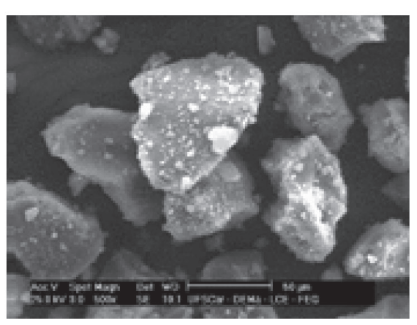

$\mathrm{SiO}_{2}-\mathrm{S}-\mathrm{SnBu}_{2}$

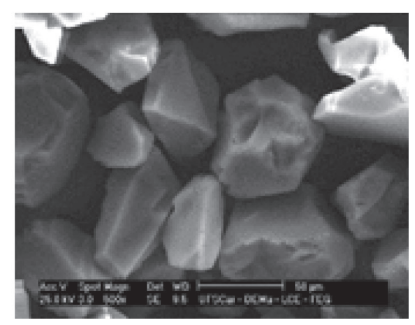

$\mathrm{SiO}_{2}-\mathrm{S}-\mathrm{SnBu}_{3}$

Figure 5. $\mathrm{SEM}$ images of $\mathrm{SiO}_{2}, \mathrm{SiO}_{2}-\mathrm{SH}, \mathrm{SiO}_{2}-\mathrm{SnBu}_{3}, \mathrm{SiO}_{2}-\mathrm{S}-\mathrm{SnBu}_{2}$, and $\mathrm{SiO}_{2}-\mathrm{S}-\mathrm{SnBu}_{3}$. 


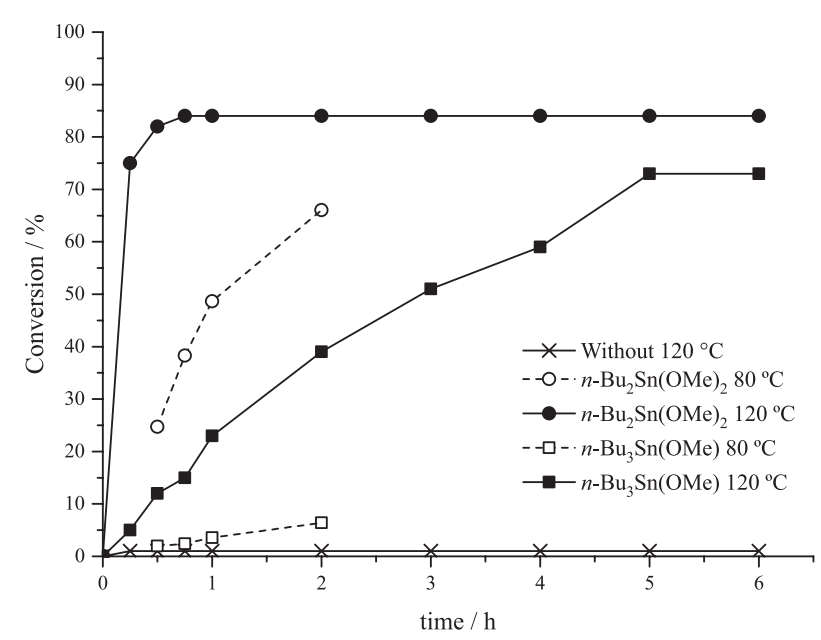

Figure 6. Conversion (\%) without catalyst and in the presence of $n$ - $\mathrm{Bu}_{3} \mathrm{Sn}(\mathrm{OMe})$ and $n-\mathrm{Bu}_{2} \mathrm{Sn}(\mathrm{OMe})_{2}$ complexes under homogeneous conditions at 80 and $120^{\circ} \mathrm{C}$ and an ethyl acetate:methanol:catalyst molar ratio of 1:5:0.005.

(85\% of conversion) relatively quickly in less than $1 \mathrm{~h}$, the $n-\mathrm{Bu}_{2} \mathrm{Sn}(\mathrm{OMe})_{2}$ homogeneous system was the most active. However, at $80^{\circ} \mathrm{C}$ it was possible to clearly observe the difference in the reactivity of the three systems with the conversion values in the order $n-\mathrm{Bu}_{2} \mathrm{Sn}(\mathrm{OMe})_{2}>>$ $\mathrm{SiO}_{2}-\mathrm{SnBu}_{2}>\mathrm{SiO}_{2}-\mathrm{S}-\mathrm{SnBu}_{2}$.

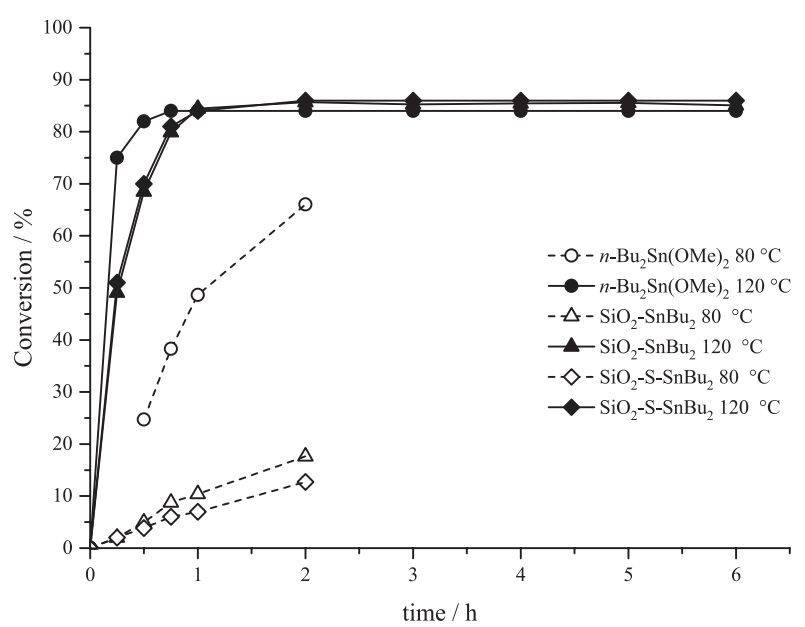

Figure 7. Conversion (\%) in the presence of $n$ - $\mathrm{Bu}_{2} \mathrm{Sn}(\mathrm{OMe})_{2}$ homogeneous complex, $\mathrm{SiO}_{2}-\mathrm{SnBu}_{2}$ and $\mathrm{SiO}_{2}-\mathrm{S}-\mathrm{SnBu}_{2}$ at 80 and $120{ }^{\circ} \mathrm{C}$ (ethyl acetate:methanol:Sn molar ratio of 1:5:0.005).

Conversely, the catalytic systems bearing three alkyl groups on $\mathrm{Sn}$, namely $n-\mathrm{Bu}_{3} \mathrm{Sn}(\mathrm{OMe}), \mathrm{SiO}_{2}-\mathrm{SnBu}_{3}$ and $\mathrm{SiO}_{2}-\mathrm{S}-\mathrm{SnBu}_{3}$, are less active than the above-described systems. Conversions of only 75,20 , and $6 \%$, respectively, were obtained at $120^{\circ} \mathrm{C}$ after $6 \mathrm{~h}$ of reaction (Figure 8). The activities of these systems at $80{ }^{\circ} \mathrm{C}$ are very low. As mentioned above. the low activity exhibited by the systems with three $n$-butyl groups on tin (under homogeneous or heterogeneous conditions) is most likely due to the steric

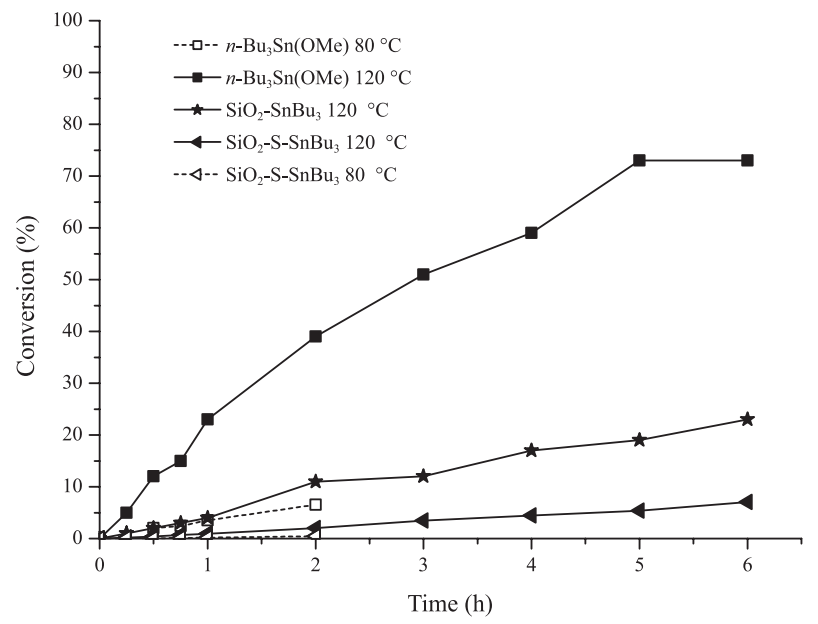

Figure 8. Conversion (\%) in the presence of $n-\mathrm{Bu}_{3} \mathrm{Sn}(\mathrm{OMe})$ homogeneous complex and $\mathrm{SiO}_{2}-\mathrm{SnBu}_{3}\left(80\right.$ and $\left.120{ }^{\circ} \mathrm{C}\right)$ and $\mathrm{SiO}_{2}-\mathrm{S}_{-} \mathrm{SnBu}_{3}\left(120{ }^{\circ} \mathrm{C}\right)$ using an ethyl acetate:methanol:Sn molar ratio of 1:5:0.005.

hindrance and the weak Lewis acid character of the active center.

Furthermore, since the amount of Sn supported on all of the solids is essentially in the same range (7-10\% of Sn, see Table 1), it may be assumed that the systems supported on the thiol-functionalized silica $\left(\mathrm{SiO}_{2}-\mathrm{S}-\mathrm{Sn}\right)$ are less active than the corresponding systems supported directly on silica $\left(\mathrm{SiO}_{2}-\mathrm{Sn}\right)$, as is observed by comparing the results for these systems shown in Figures 7 and 8. This trend can be explained due to the different polarization bond found for $\mathrm{Sn}-\mathrm{S}$ and $\mathrm{Sn}-\mathrm{O}$. The higher polarization in $\mathrm{Sn}^{\delta+}-\mathrm{O}^{\delta-}$ allows an increase of the Lewis acidity for the analogous species that bear this bond. The presence of the Sn-O bond can justify the high activity of these systems. ${ }^{45}$

The lower catalytic activities displayed by the heterogeneous systems in comparison to the analogous homogeneous systems can be related to their poor mass transfer properties. ${ }^{46}$ This disadvantage can be overcome by the recovery of the catalyst or by a development of a continuous packed bed reactor.

It is important to mention that negligible ethyl acetate conversion was obtained when only $\mathrm{SiO}_{2}$ and $\mathrm{SiO}_{2}-\mathrm{SH}$ were used, confirming that the support is catalytically inactive.

\section{Catalytic tests of reuse and leaching}

In addition to the evaluation of the catalytic activity, the reuse and the leaching of the catalytic species are critical characteristics that must be determined for the anchored systems. To investigate these properties, we performed the reactions at $120^{\circ} \mathrm{C}$ for $2 \mathrm{~h}$ using the ethyl acetate:methanol:Sn molar ratio of 1:5:0.005. After the first reaction cycle, the catalyst was properly separated from the reaction mixture, washed, and reused for more than $2 \mathrm{~h}$ of reaction. We 
emphasize that this procedure was repeated several times for each cycle. The measurements of the leached out catalytic species were performed at each catalytic cycle, enabling the supernatant obtained after the filtration procedure, i.e., without the solid, to react for additional $2 \mathrm{~h}$. This procedure was repeated again for each cycle.

Table 3 shows the ethyl acetate conversion for each reuse (cycle) of the solid catalysts. For the most reactive catalytic systems, namely $\mathrm{SiO}_{2}-\mathrm{SnBu}_{2}$ and $\mathrm{SiO}_{2}-\mathrm{S}-\mathrm{SnBu}_{2}$, that contain two alkyl groups on tin, a significant loss of catalytic activity after each reuse of the catalysts was observed. For the $\mathrm{SiO}_{2}-\mathrm{SnBu}_{2}$ system, the conversion decreased from 84 to $17 \%$ after 6 cycles and for the $\mathrm{SiO}_{2}-\mathrm{S}-\mathrm{SnBu}_{2}$ system, the conversion decreased from 85 to $8 \%$.

Despite the lowest reactivity of the $\mathrm{SiO}_{2}-\mathrm{SnBu}_{3}$ system, the decrease in the catalytic activity in each cycle was less significant. In this case, the catalytic activity decreases from 11 to $10 \%$ after 6 cycles. The $\mathrm{SiO}_{2}-\mathrm{S}-\mathrm{SnBu}_{3}$ system displays such a low activity at the conditions used that was not possible to assume any alteration in the catalytic activity after each cycle.

This decrease in the activity after several cycles can be ascribed either to the deactivation of the catalytic system
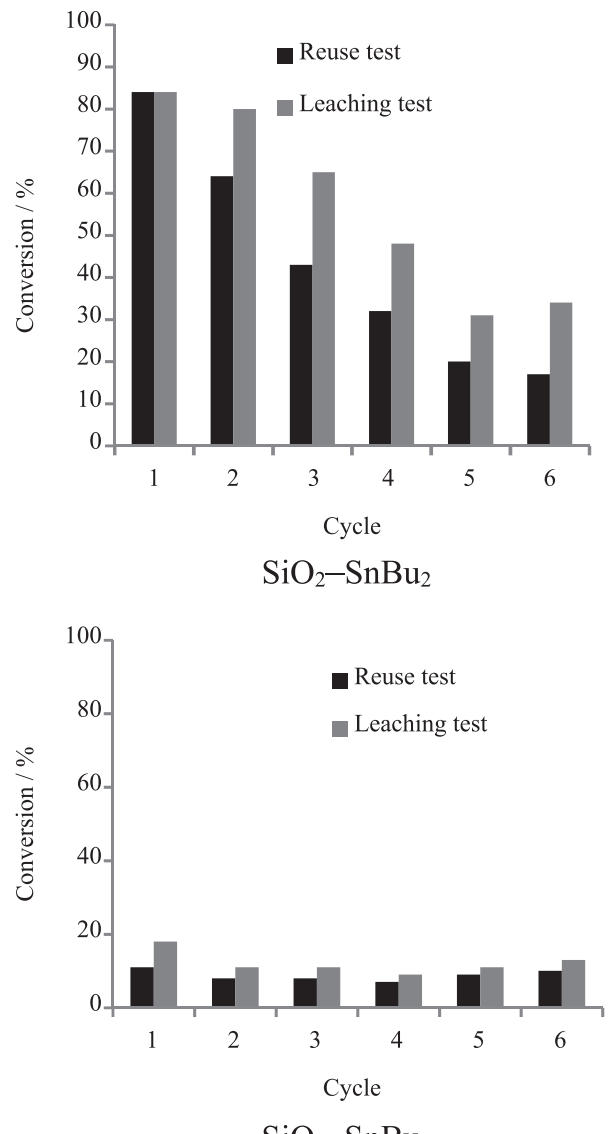

$\mathrm{SiO}_{2}-\mathrm{SnBu}_{3}$
Table 3. Conversion of ethyl acetate for each reuse (cycle) of the solid catalysts at $120^{\circ} \mathrm{C}$ for $2 \mathrm{~h}$

\begin{tabular}{lcccc}
\hline \multirow{2}{*}{ Cycle $^{\mathrm{a}}$} & \multicolumn{5}{c}{ Conversion / \% } \\
\cline { 2 - 5 } & $\mathrm{SiO}_{2}-\mathrm{SnBu}_{3}$ & $\mathrm{SiO}_{2}-\mathrm{S}-\mathrm{SnBu}_{3}$ & $\mathrm{SiO}_{2}-\mathrm{SnBu}_{2}$ & $\mathrm{SiO}_{2}-\mathrm{S}-\mathrm{SnBu}_{2}$ \\
\hline 1 & 11 & 3 & 84 & 85 \\
2 & 8 & 2 & 64 & 47 \\
3 & 8 & 1 & 43 & 33 \\
4 & 7 & 1 & 32 & 15 \\
5 & 9 & 1 & 20 & 10 \\
6 & 10 & 1 & 17 & 8 \\
\hline
\end{tabular}

${ }^{\mathrm{a} C}$ Conditions: $120^{\circ} \mathrm{C}$ for $2 \mathrm{~h}$.

or to the leaching of the catalytic species into the reaction medium. To clarify this issue, we performed tests to verify whether the active species was leached into the solution and later acted as a homogenous catalyst. In these experiments, we reacted only the supernatant of the reaction medium after eliminating all of the solids by filtration. Next, the supernatant was placed again into the reactor for another $2 \mathrm{~h}$ at $120^{\circ} \mathrm{C}$, which was repeated for each cycle. By the examination of the results presented in Figure 9, in most of the recycle tests, an increase in the conversion of the ethyl

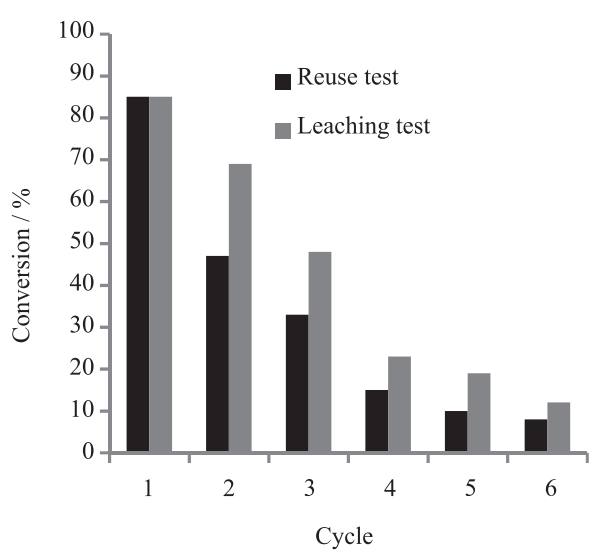

$\mathrm{SiO}_{2}-\mathrm{S}-\mathrm{SnBu}_{2}$

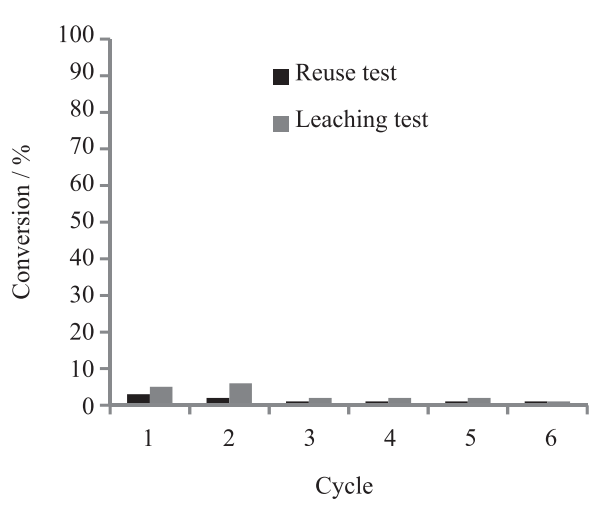

$\mathrm{SiO}_{2}-\mathrm{S}-\mathrm{SnBu}_{3}$

Figure 9. Conversion of ethyl acetate $(\%)$ in reuse test (with catalyst) and leaching tests (supernatant after more $2 \mathrm{~h}$ of reaction), for $\mathrm{SiO}_{2}-\mathrm{SnBu}_{2}$, $\mathrm{SiO}_{2}-\mathrm{S}-\mathrm{SnBu}_{2}, \mathrm{SiO}_{2}-\mathrm{SnBu}_{3}$ and $\mathrm{SiO}_{2}-\mathrm{S}-\mathrm{SnBu}_{3}$. 
acetate after $2 \mathrm{~h}$ was observed, clearly indicating that the Sn active species was leached out into the reaction medium.

Furthermore, these data corroborate the results of the reuse tests because the leaching and the decrease in the reactivity are more prominent in the $\mathrm{SiO}_{2}-\mathrm{SnBu}_{2}$ and $\mathrm{SiO}_{2}-\mathrm{S}-\mathrm{SnBu}_{2}$ systems. In the less active $\mathrm{SiO}_{2}-\mathrm{SnBu}_{3}$ and $\mathrm{SiO}_{2}-\mathrm{S}-\mathrm{SnBu}_{3}$ systems, the leaching is also less pronounced. This finding must be related to the presence of three butyl substituents that hinder the active center.

The leaching processes can be related to the presence of adsorbed only or weakly anchored Sn species on the support, and to evaluate the efficacy of the washing steps during the catalyst preparation, the solid $\mathrm{SiO}_{2}-\mathrm{SnBu}_{2}$ was submitted to ten washes with toluene (according to Experimental section), and Sn content was determined. The results show that only a small variation in the $\mathrm{Sn}$ content (approximately $0.2 \%$ ) was detected, suggesting that the weakly anchored groups are not responsible for the observed leaching during the reactions.

The use of similar strategies to immobilize $\mathrm{Sn}$ complexes has been reported in the literature, and no significant leaching was observed during transesterification reactions in those studies. ${ }^{28}$ However, it is important to highlight that the reactions examined in previous studies involve less polar substrates (as aromatic esters and long chain alcohols) compared to those used in this work (ethyl acetate and methanol), suggesting that the polarity of the reaction medium can cause the rupture of the bonds present in the anchored complexes.

To highlight this point, we investigated several reactions of benzyl benzoate in the presence of ethanol $\left(2.5 \mathrm{~mL}\right.$ ), at $2 \mathrm{~h}$ and $120^{\circ} \mathrm{C}$, employing $\mathrm{SiO}_{2}-\mathrm{SnBu}_{2}$ as the catalyst, with the benzyl benzoate:ethanol:Sn molar ratio of 1:5:0.005. Figure 10 presents the conversions obtained for three reuses of the catalyst and three leaching tests. It is important to mention that the conversion of benzyl

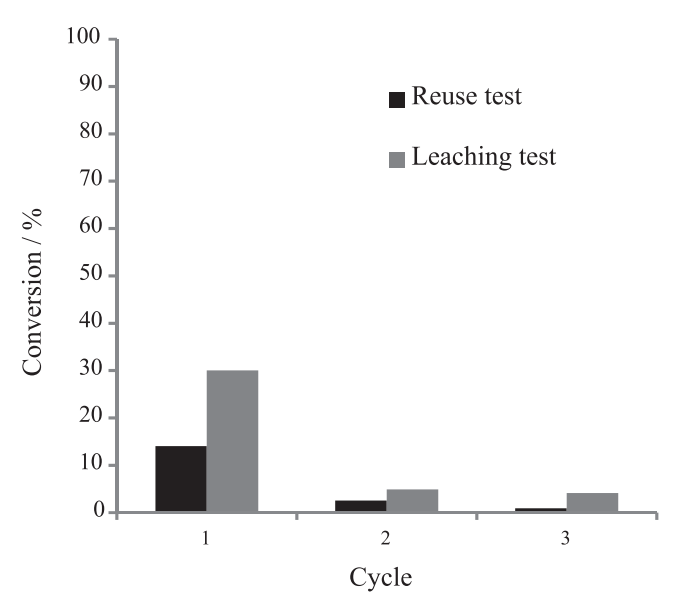

Figure 10. Conversion of benzyl benzoate $(\%)$ in reuse test (with catalyst) and leaching tests (supernatant after more $2 \mathrm{~h}$ of reaction), for $\mathrm{SiO}_{2}-\mathrm{SnBu}_{2}$. benzoate without a catalyst is negligible at these reaction conditions.

Based on the results shown in Figure 10, it is plausible to assume that the conversions of benzyl benzoate and ethanol ( $14 \%$ for the first cycle) using the same conditions and catalyst are lower than those obtained for ethyl acetate and methanol (84\%) (Figure 9), and this behavior can be related to the weak reactivity of the substrates. Regarding the reuse and leaching assays, it was observed that the catalyst loses its activity after it is reused, which is certainly due to the occurrence of leaching processes. Thus, regardless of the polarity of the substrates, deactivation due to leaching processes occurs.

Characterization of tin(IV) complexes anchored after use in the transesterification reaction

The heterogeneous catalysts after the reuse were characterized for comparison with fresh catalysts. The Sn content results (determined by ICP OES) confirm the occurrence of leaching because a decrease in the fraction of Sn on the solid after the reuse tests is observed (Table 4). However, it was observed that for all of the heterogeneous systems, some $\mathrm{Sn}$ remain anchored to the supports, even after several reaction cycles. The same tendencies were observed by other techniques (FTIR, Raman or by the determination of thermogravimetric and textural characteristics) and the results are presented as Figures S8-S12 and Tables S1 and S2 (SI section).

Table 4. Tin content before and after catalytic cycles

\begin{tabular}{lcc}
\hline \multirow{2}{*}{ Catalyst } & \multicolumn{2}{c}{$\mathrm{Sn} /$ wt.\% } \\
\cline { 2 - 3 } & Before $1^{\text {st }}$ cycle & After several cycles \\
\hline $\mathrm{SiO}_{2}-\mathrm{SnBu}_{3}$ & 7.4 & $1.3^{\mathrm{a}}$ \\
$\mathrm{SiO}_{2}-\mathrm{SnBu}_{2}$ & 7.3 & $2.7^{\mathrm{a}}$ \\
$\mathrm{SiO}_{2}-\mathrm{S}-\mathrm{SnBu}_{3}$ & 7.6 & $2.6^{\mathrm{b}}$ \\
$\mathrm{SiO}_{2}-\mathrm{S}-\mathrm{SnBu}_{2}$ & 9.8 & $3.6^{\mathrm{b}}$ \\
\hline
\end{tabular}

${ }^{\mathrm{a} A f t e r} 10$ cycles; ${ }^{\text {bafter }} 6$ cycles.

\section{Conclusions}

This study demonstrated the feasibility of anchoring organotin compounds on silica by two methods: (i) direct interaction with nonfunctionalized silica $\left(\mathrm{SiO}_{2}-\mathrm{Sn}\right)$; and (ii) interaction with thiol-functionalized silica $\left(\mathrm{SiO}_{2}-\mathrm{S}-\mathrm{Sn}\right)$. Using ICP OES, we determined the amount of tin and sulfur anchored on the supports. FTIR spectra confirmed the presence of organic moieties on the silica. From the Raman spectra, it was observed that the signal due to the presence of the thiol group $(\mathrm{S}-\mathrm{H})$ disappeared 
after the anchor reaction of the tin(IV) compounds. The procedure to anchor the organotin species via the silanol or thiol groups showed the same efficacy, as observed from the essentially identical amounts of tin present on all of the solids. Under the reaction conditions used in the catalytic tests, the order of reactivity is $n-\mathrm{Bu}_{2} \mathrm{Sn}(\mathrm{OMe})_{2}>$ $n-\mathrm{Bu}_{3} \mathrm{Sn}(\mathrm{OMe})>\mathrm{SiO}_{2}-\mathrm{SnBu}_{2}>\mathrm{SiO}_{2}-\mathrm{S}-\mathrm{SnBu}_{2}>$ $\mathrm{SiO}_{2}-\mathrm{SnBu}_{3}>\mathrm{SiO}_{2}-\mathrm{S}-\mathrm{SnBu}_{3}$. Through the reuse tests, it was observed that after each reuse of the catalyst, a decrease in the ethyl acetate conversion was observed. The characterization of the heterogeneous catalysts after reuse confirmed the leaching of the tin complexes in the reaction medium. Nevertheless, the $\mathrm{SiO}_{2}-\mathrm{SnBu}_{2}$ and $\mathrm{SiO}_{2}-\mathrm{SnBu}_{3}$ systems remained active even after 10 reaction cycles (representing $20 \mathrm{~h}$ of reaction), demonstrating the advantage of the heterogenization of these systems.

\section{Supplementary Information}

Supplementary data (FTIR and Raman spectra, TG and textural analysis and SEM images) are available free of charge at http://jbcs.sbq.org.br as PDF file.

\section{Acknowledgments}

This study was financed in part by the Brazilian Federal Agency for the Improvement of Higher Education (CAPES), by the National Council for Scientific and Technological Development (CNPq), Brazilian Innovation Agency (FINEP) and Alagoas Research Foundation (FAPEAL). R. A. J., J. P. V. S. and N .S. B. express their appreciation for fellowships granted by CAPES and CNPq. S. M. P. M. and M. R. M. thank CNPq for research fellowships. For contributions, the authors thank Northeastern Technology Center (CETENE), Prof Rusiene M. de Almeida (GCARUFAL), Prof Antonio Osimar S. da Silva (LSCAT-UFAL), MSc Elaine C. O. da Silva and Prof Eduardo J. S. Fonseca (GON-UFAL), and Dr José A. S. Costa and Prof Caio M. Paranhos da Silva (LabPol-UFSCar).

\section{References}

1. Hunter, R. C.; Environ. Health Perspect. 1976, 14, 47.

2. Gaina, C.; Cristea, M.; J. Inorg. Organomet. Polym. Mater. 2009, 19, 157.

3. Ayrey, G.; Hsu, S. Y.; Poller, R. C.; J. Polym. Sci. 1984, 22, 2871.

4. Gadja, T.; Jancsó, A. In Organometallics in Environment and Toxicology: Metal Ions in Life Sciences, $1^{\text {st }}$ ed.; Astrid, S.; Helmut, S.; Roland, K. O. S., eds.; RSC Publishing: Cambridge, 2010, p. 111.
5. Brito, Y. C.; Ferreira, D. A. C.; Fragoso, D. M. A.; Mendes, P. R.; Oliveira, C. M. J.; Meneghetti, M. R.; Meneghetti, S. M. P.; Appl. Catal., A 2012, 443, 202.

6. Silva, E. C.; Mendes, P. R.; Brito, Y. C.; Meneghetti, M. R.; Meneghetti, S. M. P.; Catal. Commun. 2016, 78, 7.

7. Jousseaume, B.; Noiret, N.; Pereyre, M.; Saux, A.; Francès, J. M.; Organometallics 1994, 13, 1034.

8. Silva, M. A.; Santos, A. S. S.; Santos, T. V.; Meneghetti, M. R.; Meneghetti, S. M. P.; Catal. Sci. Technol. 2017, 7, 5750.

9. Ueno, Y.; Chino, K.; Watanabe, M.; Moriya, O.; Okawara, M.; J. Am. Chem. Soc. 1982, 104, 5564.

10. Fan, B.; Li, H.; Fan, W.; Zhang, J.; Li, R.; Appl. Catal., A 2010, $372,94$.

11. Zhang, Y.; Wang, S.; Xiao, Z.; Chen, T.; Wang, G.; Res. Chem. Intermed. 2016, 42, 7213.

12. Toupance, T.; Renard, L.; Jousseaume, B.; Olivier, C.; Pinoie, V.; Verbruggen, I.; Willem, R.; Dalton Trans. 2013, 42, 9764.

13. Mercier, F. A. G.; Biesemans, M.; Altmann, R.; Willem, R.; Organometallics 2011, 20, 958.

14. Angiolini, L.; Caretti, D.; Mazzocchetti, L.; Salatelli, E.; Willem, R.; Biesemans, M.; Appl. Organomet. Chem. 2005, $19,841$.

15. Camacho-Camacho, C.; Biesemans, M.; Poeck, M. V.; Mercier, F. A. G.; Willem, R.; Darriet-Jambert, K.; Jousseaume, B.; Toupance, T.; Schneider, U.; Gerigk, U.; Chem. - Eur. J. 2005, $11,2455$.

16. Poelmans, P.; Pinoie, V.; Verbruggen, I.; Biesemans, M.; Assche, G. V.; Deshayes, G.; Degee, P.; Dubois, P.; Willem, R.; Appl. Organomet. Chem. 2007, 21, 504.

17. Pinoie, V.; Biesemans, M.; Willem, R.; Appl. Organomet. Chem. 2010, 24, 135.

18. Pinoie, V.; Poelmans, K.; Miltner, H. E.; Verbruggen, I.; Biesemans, M.; Assche, G. V.; Mele, B. V.; Martins, J. C.; Willem, R.; Organometallics 2007, 26, 6718.

19. Wight, A. P.; Davis, M. E.; Chem. Rev. 2002, 102, 3589.

20. Santos, D. O.; Santos, M. L. N.; Costa, J. A. S.; Jesus, R. A.; Navickiene, S.; Sussuchi, E. M.; Mesquita, M. E.; Environ. Sci. Pollut. Res. 2013, 20, 5028.

21. An, Y.; Chen, M.; Xue, Q.; Liu, W.; J. Colloid Interface Sci. 2007, 311, 507.

22. Adam, F.; Osman, H.; Mohammed, K. H.; J. Colloid Interface Sci. 2009, 331, 143.

23. Kang, L.; Cai, Y.; Peng, Y.; Ying, X.; Song, G.; Mol. Diversity 2011, 15, 109.

24. Wu, J.; Ling, L.; Xie, J.; Ma, G.; Wang, B.; Chem. Phys. Lett. 2014, 591, 227.

25. Brunauer, S.; Emmett, P. H.; Teller, E.; J. Am. Chem. Soc. 1938, $60,309$.

26. Kuzminska, M.; Kovalchuk, T. V.; Backov, R.; Gaigneaux, E. M.; J. Catal. 2014, 320, 1. 
27. Najafi, M.; Rostamian, R.; Rafati, A. A.; Chem. Eng. J. 2011, $168,426$.

28. Pugin, B.; Dubuis, B.; Muller, A.; US pat. 2002/0022731 A1, 2002.

29. Freitas, A. J. D.; Santos, J. H. Z.; Meneghetti, S. M. P.; Meneghetti, M. R.; J. Appl. Polym. Sci. 2010, 119, 3051.

30. Chen, X.; Jiang, J.; Yan, F.; Tian, S.; Li, K.; RSC Adv. 2014, 4, 8703.

31. Al-Oweini, R.; El-Rassy, H.; J. Mol. Struct. 2009, 919, 140.

32. Christy, A. A.; Int. J. Eng. Technol. 2012, 4, 484.

33. Tobin, M. C.; J. Mol. Spectrosc. 1960, 5, 65.

34. Peach, M. E.; Can. J. Chem. 1968, 46, 211.

35. Veith, M.; Auvray, N.; Huch, V.; Braunstein, P.; C. R. Chim. 2005, 8, 57.

36. Wu, S.; Li, F.; Xu, R.; Wei, S.; Li, G.; J. Nanopart. Res. 2010 , 12, 2111.

37. Thompson, W. R.; Pemberton, J. E.; Chem. Mater. 1993, 5, 241.

38. Capeletti, L. B.; Baibich, I. M.; Butler, I. S.; Santos, J. H. Z.; Spectrochim. Acta, Part A 2014, 133, 619.
39. Qiu, H.; Jiang, Q.; Wei, Z.; Wang, Z.; Liu, X.; Jiang, S.; J. Cromatogr. A 2007, 1163, 63.

40. Thommes, M.; Kaneko, K.; Neimark, A. V.; Olivier, J. P.; Rodriguez-Reinoso, F.; Rouquerol, J.; Sing, K. S. W.; Pure Appl. Chem. 2015, 87, 1051.

41. Gregg, J. S.; Sing, W. S. K.; Adsorption, Surface Area and Porosity, $2^{\text {nd }}$ ed.; Academic Press: London, 1982.

42. Fan, B.; Zhang, J.; Li, R.; Fan, W.; Catal. Lett. 2008, 121, 297.

43. Araújo, J. A.; Cardoso, D.; J. Mol. Catal. A: Chem. 2016, 422, 51.

44. Nunes, R. S.; Altino, F. M.; Meneghetti, M. R.; Meneghetti, S. M. P.; Catal. Today 2017, 289, 121.

45. Filgueiras, C. A.; Quim. Nova 1998, 21, 176.

46. Lee, W.-C.; Chem. Eng. J. 1992, 50, 79.

Submitted: January 22, 2019

Published online: May 24, 2019 